Article

\title{
Historical and Spatial Layers of Cultural Intimacy: Urban Transformation of a Stigmatised Suburban Estate on the Periphery of Helsinki
}

\author{
Pekka Tuominen \\ Department of Media and communication studies, University of Helsinki, 00014 Helsinki, Finland; \\ E-Mail: pekka.tuominen@helsinki.fi
}

Submitted: 30 June 2019 | Accepted: 16 December 2019 | Published: 27 February 2020

\begin{abstract}
Kontula, a suburban estate at the margins of Helsinki, Finland, has been plagued by a notorious reputation since its construction in the 1960s. At different moments in history, it has reflected failed urbanity, with shifting emphases on issues such as rootlessness, segregation, intergenerational poverty, and unsuccessful integration of immigrants. Unlike many other suburban estates in Helsinki, it has become a potent symbol of the ills of contemporary urbanity in the vernacular geography of the city. Based on ethnographic fieldwork, this article explores how its inhabitants experience the dynamic between the internalised stigma and their responses to it. The focus is on how historically formed and spatially defined senses of belonging and exclusion shape their everyday lives and how they have found ways to challenge the dominant perceptions about their homes and neighbourhoods. I argue that an understanding of cultural intimacy, conceptually developed by Michael Herzfeld, offers a useful way to approach the tension between essentialised categories and lived realities. Rather than simply limiting their agency, the shared stigma enables inhabitants to form powerful senses of belonging. The article emphasises how culturally intimate understandings employ both complex historical trajectories and shifts in relative location to question and confront the stigma in the language of mutual trust and belonging.
\end{abstract}

\section{Keywords}

cultural intimacy; ethnography; Finland; resistance; territorial stigma; urban marginalisation; urban transformation

\section{Issue}

This article is part of the issue "New Research on Housing and Territorial Stigma" edited by Margarethe Kusenbach (University of South Florida, USA) and Peer Smets (Vrije Universiteit Amsterdam, the Netherlands).

(C) 2020 by the author; licensee Cogitatio (Lisbon, Portugal). This article is licensed under a Creative Commons Attribution 4.0 International License (CC BY).

\section{Introduction}

"If you survive here, you survive everywhere," Jamal told me with a wry smile. He was one of the teenagers, just turned sixteen, hanging around the run-down open-air shopping centre of Kontula district almost every day. We were on the eastern periphery of Helsinki, accessible in only 15 minutes from the central districts of the city by a frequent metro connection, but rarely visited by nonresidents. Tonight was special because an NGO with the aim of connecting with disadvantaged youths had arrived in Kontula: They had parked their bus by the metro station and would welcome everyone under eighteen for cheap (decaffeinated) coffee, tea and snacks with an opportunity to warm up inside, play board games, and chat. "We run this place. We don't care what the others think about us," Jamal continued with intense pride in his voice.

The bus had toured some other districts reputed to be "problem areas" and we discussed the range and scale of their issues with a group of volunteers, mostly from the local youth centre. One of the social workers told us that the situation with the youths in their previous location had been dire. After hearing this, Jamal interrupted us and wanted to know whether there were other places as bad as Kontula. Social workers took his question seriously and began to discuss the differences related to the size, demography, and other factors of the other districts but this did not satisfy him. He wanted to know which one ranked at the top in this sense and was sure that it 
would be Kontula. The other youths gathered around to support his view.

I asked Jamal, casually, how well he knew these other places, had he seen their realities with his own eyes. The atmosphere suddenly became very tense and serious. This was not the right question in this context. We were no longer comparing different districts but alluding to the shrinking of the lifeworld into the narrow confines of the suburban estate. "The centre of Helsinki is just fifteen minutes from here by metro, but we rarely go there" Jamal continued, "we take the metro for just two stops to Itäkeskus [a big mall], almost never further. What is there in the centre for us? As a Somali immigrant I feel much more comfortable here." His boastful demeanour had changed into hesitancy and the discussion stopped. Jamal looked at the ground visibly ashamed. The silence was broken by Jesse, who had earlier taken pride in his grandparents being among the original inhabitants of Kontula: "Yes, there are people who say that we are stuck in this place. Maybe it is true but is it really a problem? Kontula has all I need. People say this is a shithole, but we don't care." The other youth agreed, the uneasy undercurrent had been driven away and it was time to move on.

This encounter brings together several key themes of my argument: the hierarchical relations between urban spaces; the sense of the peripherality of one's lifeworld and the ambivalence of pride; and shame associated with it. Here, the culturally intimate affirmation of survival skills, insistence on Kontula ranking at the top of Helsinki's problem areas, and the claim of not caring about the opinions of the others suddenly turned into consideration of isolation and marginalisation before the sense of pride was retrieved. Within the dominant spatial hierarchy of Helsinki, Kontula is at the bottom.

The reputation of Kontula is acknowledged by its inhabitants as well as Finns who have never set foot in the area. With its towering blocks of flats and busy but run-down shopping centre, it signifies urban marginality, distanced from the exemplary urbanity of the city centre, while simultaneously not qualifying for the category of lush suburbia, despite its pockets of wealthier middle-class neighbourhoods. The term suburban estate brings together the contradictory attributes of the whole district. Built primarily in the 1960s and 1970s to accommodate large-scale migration from the countryside to the cities, it has a long history as a symbol of urban rootlessness, social problems, and failed integration of the immigrants, to the degree that casual comments such as "if this goes wrong I will soon be living in Kontula" or "if things don't change, my neighbourhood will become like Kontula" are widespread and ubiquitous. However, the difference between the predominant representations and social realities are recognised by the inhabitants and often used to their advantage. It is hard work to find a balance between the denigrating and stigmatising discourses from those in power and the culturally intimate senses of belonging and local pride.
My analysis is based on a discussion of Loïc Wacquant's influential theories of territorial stigma, with emphasis on how their notions of agency can be expanded-especially in relation to the sociospatial orientation (Taylor, 1989, 1992, 1995), relative location (Green, 2012) and embodied senses of history (Faubion, 1993). Moreover, I discuss the possibilities of challenging the stigma in particular contexts and introduce a perspective influenced by Michael Herzfeld's (2016) theory of cultural intimacy, concentrating on successful attempts to challenge the dominant views from the margins and to establish powerful senses of community, founded largely on notions of their imperfection and shared colloquial sociality. The principal objective of the article is to study the prevalence of stigma in the everyday lives of Kontula's inhabitants, its relation to spatially and historically ordered senses of sociality and the attempts to reverse the stigma with various tactics and degrees of success. I begin with a discussion of the prominent theoretical streams on stigmatisation and the specific features of my ethnographic study of everyday life in Kontula, move on to examine how spatial hierarchies are related to historical changes and, in the last section of the article, observe different ways to challenge the stigma through culturally intimate notions of sociality.

\section{Spatially Defined Stigma: Theory and Literature}

Territorial stigmatisation is a loaded concept, its academic applications can be quite different from the essentialised media representations and, especially, from the first-hand experience of life in the near-constant presence of stigma. There is a vast literature on this topic, developed primarily with the theories of Wacquant (2007, 2008,2010 ) and his associates (see especially Vol. 46 of Environment and Planning $A$, with several articles applying the theory to different geographic contexts). They have defined it as a specific historical condition of societies since the end of the 20th century, after the dissolution of neighbourhoods emblematic of the FordistKeynesian phase of industrial capitalism (Wacquant, Slater, \& Pereira, 2014, p. 1270). My aim is to discuss how the theory relates to a Finnish case of urban marginality, a succession of historical changes that form a palimpsest in which visible traces of the earlier forms still influence the contemporary realities. My focus lies specifically in the hierarchisation of urban space and internalisation of the stigma as context-specific processes that escape the dominant designations in often surprising ways. A brief glance into the influences of Wacquant helps us to understand the dynamics of his theory.

The concept of stigma in the social sciences is ambiguous in relation to its fixity. Erving Goffman's (1963) widespread formulation does not include place of residence as one of the factors that can disqualify the individual, while Wacquant argues that "territorial infamy displays properties analogous to those of bodily, moral and tribal stigmata" (2007, p. 67). Even so, ter- 
ritorial stigma differs from the other types for it can be quite easily dissimulated or even annulled by geographical mobility (Wacquant, 2007). Wacquant considers his theory of territorial stigmatisation as bringing together Goffman's view with Bourdieu's theory of symbolic power (Wacquant et al., 2014, p. 1272).

Furthermore, both Bourdieu (1999, p. 123) and Wacquant $(2007$, p. 68) emphasise the role of media and state-led campaigns to enforce the internalisation of territorial stigma. According to their findings, representations of stigmatised areas exercise immense power among both their inhabitants and the wider society, establishing a hierarchical view of the society that conditions their subjection to the dominant frameworks. This is often based on rumours and sensational stories, especially in the tabloid media. The consequences are devaluation of the self and corrosion of the social ties which lead to inhabitants' "strategies of mutual distancing and lateral denigration; they retreat into private sphere of the family; and they exit the neighbourhood (whenever they have the option)" (Wacquant, 2008 , p. 116). In the same vein, Bourdieu sees no escape other than flight towards other sites, which is usually made impossible by a lack of resources (1999, p. 129). According to Wacquant, this dynamic presents a selffulfilling prophecy when the negative representations begin to guide the lives of the residents who, in turn, end up reinforcing them $(2008$, p. 116). For both, the internalisation of the stigma is extremely powerful, and the hierarchy of different spaces remains straightforward and largely unquestioned. Stigmatised areas signify only problems and their residents are defenceless against the distorted media representations. In these analyses the geographic focus is on the French banlieues and the predominantly black neighbourhoods in the US.

In their article examining how territorial stigma is internalised in Aalborg East, Denmark, Jensen and Christensen (2012) draw attention to the differences between interactionist perspectives based on Goffman's work and those heavily influenced by Bourdieu's theories of habitus and symbolic violence. While the former address internalisation, they refer to awareness of the stigma, not necessarily the internalisation of worthlessness associated with it. In contrast, Bourdieu and Wacquant argue that the marginalised groups incorporate their social degradation as a result of their stigmatisation (Jensen and Christensen, 2012, p. 77). However, in his later work, Wacquant allows more room for strategies to challenge the prevailing order, ranging from recalcitrance to resistance, in order to defend the stigmatised area against accusations or to take an indifferent stance toward them (Wacquant et al., 2014, p. 1276). In the same article, he also defends the complementariness of Goffman's and Bourdieu's work: the first working from below, "across encounters and their aggregations into organisations"; the second from above, "following the flow of efficient representations from symbolic authorities" (Wacquant et al., 2014, pp. 1272-1273).
The aim of my analysis is not to discredit these approaches but to suggest how they could be made more sensitive to contradictions and the rapidly-changing contexts of everyday realities. While the powerful representations of the media, state actors and even researchers have been successful in designating the territorial stigma of Kontula, informal discussions with the residents in diverse contexts often reveal that reactions to stigmatisation are varied, with wide-ranging consequences. I find the theoretical framework of Wacquant flexible enough to accommodate these responses. In the same vein, Kirkness (2014), August (2014), and Kallin \& Slater (2014) have examined the ways to question and to challenge stigmatisation creatively. I began with a depiction of an encounter with Jamal and his friends, in which boastful pride quickly turned into hesitancy, even shame, about isolation within the extended spatial hierarchy. If nonresidents associate Kontula with strong territorial stigma, its inhabitants cannot be unaffected by it. However, the straightforward and reified designation from the outside, covering the whole gamut of urban ills, meets a diverse and complex social reality of the everyday lives of the inhabitants who have been exposed to the stigma daily. The spatial hierarchy is continually redefined along different scales, from neighbourhoods to districts and can be based on very different values. It establishes a specific order but not necessarily territorial stigma. As my ethnographic accounts show, the residents have become extremely sensitive to its different dimensions and understand its dynamics in a very detailed way.

The stigma is not frozen in time but always related to the sociospatial context and its power relations. Its location is relative, and its meaning "depends upon its relations with, and separations from other places" (Green, 2012, p. 6). In order to understand the value of the place, depending on its hierarchically ordered position relative to other places, we have to concentrate on the particular value system that is used to create an order (Green, 2012). Furthermore, the meaning does not depend on just the contemporary representations but on an immensely detailed history. All the shades of stigma over the years have implied shifts in the relative location of Kontula and its position in differently defined hierarchies. Inhabitants, especially those who have lived in Kontula for a long time, have become experts in reacting to the stigmatisation. The expertise consists of both embodied knowledge of appropriate behaviour and a distinguished ability to reflect upon its dynamics (cf. Taylor, 1992).

Michael Herzfeld's (2016) theory of cultural intimacy provides a thought-provoking framework to bring together the questions of spatial hierarchy, socioculturally appropriate practices, and the role of essentialism in social life. It helps us to understand the sense of local pride in a district that has suffered for decades from a stigma imposed from the outside. Herzfeld defines cultural intimacy as "the recognition of those aspects of an officially shared identity that are considered a source of external embarrassment but that nevertheless provide in- 
siders with their assurance of common sociality," "the self-stereotypes that insiders express ostensibly at their own collective expense" $(2016$, p. 7). It offers a way to express the value of informal social relations in everyday life, away from the gaze of the authorities and their strict definitions of appropriateness. As my field data show, there are moments when the long history of territorial stigmatisation turns into pride-hesitant or boastfulabout the locality. Bourdieu's view of the downward spiral, of the "stigmatised area degrading its inhabitants, who, in return, symbolically degrade it" (1999, p. 129), leading to their common excommunication, does not recognise how the stigma can also result in a powerful sense of community that relies on its very stigmatisation for its solidarity.

\section{Methods}

My research is based on ethnographic fieldwork conducted in Kontula during 2017 and 2018 (12 months/3 months). The principal method of participant observation has been supported by semi-structured interviews, historical studies of the area, media accounts, and statistical information. The ethnographic data presented here is founded on the patterns that have emerged from countless informal encounters with people from very different ages and backgrounds. I conducted over 30 interviews, mostly on the history and the urban transformation of the area (of durations lasting from half an hour to several hours); they acted mostly as support for participant observation. The core of my argument is mostly based on following the rhythms of everyday life, balancing between the ordinary and extraordinary, contradictions and paradoxes that are specific to particular contexts, rather than to stable opinions and identitieshumanisation of the subjects instead of their depiction in abstract terms (cf. Duneier, 2002, p. 1575). These daily encounters were recorded comprehensively in my field diary and the more relevant sections of the interviews were transcribed. Many of the identified sociocultural issues were repeatedly brought up with the informants and discussed in different groups. Over the course of the fieldwork, I was able to reach people from very different backgrounds, but the focus remained on those who frequented the central open-air shopping centre and were active users of its services.

My own position during the fieldwork evolved from someone who was new to the area into one of the people who "were always around." As a white male with a university education and a steady income I stood out from the crowd, principally because many of the people got to know me as "Doctor," a nickname I was given during the early stages of my fieldwork. To counterbalance this, my childhood and youth as an inhabitant of another stigmatised suburban estate in Helsinki helped to facilitate the dialogue more than I expected. At some point, many of the discussions tended to touch on the difficulty of explaining the realities of Kontula to outsiders. In these situ- ations, I heard frequently that I was someone who would know from experience "what it was like."

Following Alpa Shah, I consider participant observation "not merely a method of anthropology but a form of production of knowledge through being and action; it is praxis, the process by which theory is dialectically produced and realized in action" (2017, p. 45). The ethnographic method does not just confirm hypotheses but engages in producing a more detailed grasp of social realities with the informants. Its aim is to tease out the pragmatic logic of everyday life, how different practices make sense in ways that people are not necessarily aware of (Graeber, 2007, p. 305). To assess a phenomenon such as multifaceted as stigmatisation, long-term involvement in the lives of the informants provided different and often conflicting views compared to data from interviews and more formal questions. The gradual gaining of trust was essential in reaching beyond the expected reactions about the characteristics of the area.

Here, my findings are expressed in a form of three narrative accounts by local inhabitants whose names have been changed to protect their privacy. They were selected to represent the systematic collection of impressions, characterisations, and memories of spaces and traces of history, thus bringing together the diverse perspectives towards stigmatisation in the area. They are not based on experiences shared by all inhabitants but explore the ways in which stigma is encountered and reacted to, referring to several recurring patterns in my field data. In this case, the shared experiences of teenagers from both immigrant and native Finnish backgrounds, the native-born long-term residents in the social housing estate they love and an Afghani immigrant with a strong identification with Kontula, point to the range of variations. The analysis of my field data has followed the identification of the most prevalent themes in the everyday lives of my informants but also paid attention to the silences and situations in which they struggled to establish coherent narratives of their lifeworld.

The overriding focus in my fieldwork has been to understand how people accomplish a positive sense of belonging despite conflicting sociocultural norms and subjection to stigma (cf. Duneier, 1999, p. 341). This is not to belittle the serious social problems in Kontula, but the statistics regarding employment, health, and crime in the area place it above many other districts in Helsinki that do not suffer from territorial stigmatisation to the same degree.

\section{Historical Layers and Spatial Hierarchies of Kontula}

The Kontula suburban estate reflects closely the ideals of Finnish urban planning in the 1960s. Not modelled after the American suburbia, nor after the housing estates in the British context, the Finnish suburban housing estate (lähiö) combines characteristics of both (see Ilmonen, 2016, and Stjernberg, 2019, for a discussion of definitions). The emphasis was on constructing separate 
housing areas with their own centres for essential services and allocation of blocks of flats around them, leaving room for green areas between the concentrations of buildings (Lento, 2006). Approximately one million Finns currently live in the hundreds of suburban estates, most of them built in the 1960s and 1970s (Stjernberg, 2019, p. 1). However, few of them carry any territorial stigma.

The local detailed plans for Kontula were released in 1963-1965 and the construction began principally with the aim of offering affordable housing in a city that was growing fast. For many of the original residents, moving into Kontula meant substantial improvement in their living conditions. Compared to small flats in the inner-city areas, Kontula offered spacious rooms, balconies as well as modern kitchen facilities and bathrooms, making suburban estates a popular option for working-class families (Kokkonen, 2002; see Kirkness, 2014, for similarities in the French context). Located on the urban periphery of Helsinki, at first accessible only by unsealed roads and irregular bus connections, Kontula quickly became a powerful symbol of both modernisation and urban rootlessness, a space somewhere between the city and the countryside, but not really part of either (Kokkonen, 2002). This kind of liminality is one dimension of the stigma that has haunted Kontula ever since. However, the narrative of segregation has gradually changed its form from the lack of transport connections into self-imposed isolation based on not being accepted in the other parts of the city. Even the newcomers to the area quickly adopt this narrative with its distinct historical emphases.

Since its construction, the media representations of Kontula concentrated on the social problems of the area, the lack of meaningful activities for its youth and the poor-quality construction (Roivainen, 1999). The stigma imposed by the media intensified at the beginning of the 1990s when Finland was in deep recession and the unemployment figures soared, especially in the areas with large working-class populations. Kontula became an emblem of recession and a favourite spot for journalists looking for a story about its consequences. In the 2000s, the stigma concentrated around claims of uncontrolled immigration and failed integration.

Despite changes in the media attention over recent decades, the reports often follow a similar line of argument. The most common approach to Kontula is to confirm its status as a problem area. The focus might be on why people are leaving; according to this widespread narrative, the reasons are substance abuse in the area and tensions within the multicultural environment (Jaskari, 2018). It can also be about how the ubiquity of low levels of education in the area normalises it among the youth (Vehkasalo, 2017a). In another recent case, reporting the crime statistics in different parts of Helsinki with a focus on Kontula did not really support the conclusions drawn from them but used Kontula as an example of a crime-ridden area (Pajuriutta \& Saarinen, 2017). This variety of media representation expresses the "pathological discourse" that understands the problems rooted in the large spatial concentration of the poor and the marginalised (Hastings, 2004).

Another prominent type of discourse, focussing on the structural explanations of the problems (Hastings, 2004), often proclaims grave warnings about the future of the marginalised suburban estates, emphasising that the segregation development must stop (Lepistö, 2018). These narratives closely follow the themes and narratives Kearns, Kearns, and Lawson (2013) analysed as negative, mixed, and positive media representations in two inner-city mass housing estates in Glasgow. All the previous examples express the negative type. For the mixed representations, the most common varieties in both Glasgow and Kontula are the seemingly positive stories of community initiatives which, however, never fail to mention the social problems in the area and "working against the odds" by the inhabitants (Vehkasalo, 2017b; cf. Kearns et al., 2013, p. 590). Another type of mixed media representation regarding Kontula consists of readers' letters criticising the media portrayals and pointing out positive developments despite the problems. This is also the case in Glasgow. On the positive side the stories are few, mostly concentrating on individual success stories and the rapid regeneration. In an exemplary case, rundown pubs are being replaced by affordable but good quality Middle Eastern restaurants (Nelskylä, 2016).

Statistically, there is no real basis for explaining the stigmatised position of Kontula. Its socioeconomic status is low but not markedly lower than many other districts that have not become symbols of failure. Furthermore, the current socioeconomic factors are not enough to explain the stigma: Kontula was already stigmatised in the 1970s, when it was not evidently disadvantaged (see Stjernberg, 2019, p. 153).

A significant concentration of immigrants, low quality housing stock, or high proportion of social housing are also inadequate factors when explaining the stigmatisation of Kontula. In comparison with many districts in Europe, the percentage of inhabitants with an immigrant background is relatively low. However, the current figure is that $36.2 \%$ of people do not speak the official languages of Finland (Finnish, Swedish or Sámi) as their mother tongue, one of the highest in Finland (City of Helsinki, 2019). In 2018, the population of Kontula was 14418 but a better figure is 38771 , the population of the larger Mellunkylä district, including adjoining neighbourhoods, often associated with Kontula and lacking clear boundaries in the minds of the inhabitants. In 2016, $18.5 \%$ of the inhabitants were unemployed (compared to $12 \%$ in Helsinki), the proportion of social housing was significantly higher than in the central districts and $20 \%$ of the inhabitants received welfare benefits, compared to $11.9 \%$ in Helsinki (City of Helsinki, 2018).

However, these reifications and statistics ignore the diversity of Kontula's neighbourhoods over the course of their history. Many studies of territorial stigmatisation and ghettoisation depict neighbourhoods in which poverty is an omnipresent condition (see Duneier, 2016; 
Wacquant, 2010). While Kontula is routinely called a problem area or even a ghetto in media representations and colloquial conversations, its reality is vastly different. On looking more closely, it has a wide variety of housing options, ranging from the renowned concrete blocks to some wealthy pockets with spacious detached houses.

Even within the stock of social housing there is diversity that has historical roots. Following the values of the social democratic welfare state, the question of social mixing was integral to urban planning from the 1960s, the time when the building of Kontula began. In the 1960s and 1970s, the suburban estates had both non-subsidised and social housing and after 1974, the housing blocks had to contain both varieties (Vaattovaara \& Kortteinen, 2003). In the case of social housing, the aim was to avoid locating the tenants with the lowest income levels in the same buildings (Dhalmann \& Vilkama, 2009). It is important to note here that the policy of social mixing in this context operated differently from its contemporary variant, associated with New Urbanism, and often fostering gentrification (see August, 2014; Kallin \& Slater, 2014). This internal variety is mostly lost in the mainstream media accounts. The following vignette presents a way of maintaining the balance between the reputation and social reality, acknowledging the boundaries within the district and the impact of the influences from the outside.

\section{Challenging the Stigma}

\subsection{Hidden Paradise}

Kirsi had been living in Kontula for a long time, almost three decades, and had just retired from her job as a nurse. Her flat was in one of Finland's largest concentrations of public housing which had a notorious reputation, even within the standards of Kontula. It was only fifteen minutes' walk from the metro station and the shopping centre, but the neighbourhood was rarely visited by nonresidents. It was just forest and houses, as I heard many say, and social problems, as others would add. The local grocery store had closed years ago; in addition to the NGO-run clubhouse providing cheap food, newspapers, and handicraft workshops, there was just a local pub and a football field.

Kirsi was aware of living in the most stigmatised part of an already stigmatised district and had had time to think about what it meant. When we first met, I remember her complaining about the delayed building repairs, restlessness, and the lack of services. She told me later that she had thought I was working for one of the numerous projects to improve the disadvantaged area. After we got to know each other better, our discussions were often about the ambivalent relationship she had towards her neighbourhood. One day when we were walking alongside the almost identical grey tower blocks, she began to contemplate: "It is funny, when I am walking with you, I am constantly thinking about what you think about this place. For many, these are some of the ugliest build- ings in Helsinki. When you ask people about their homes, they all say that they want to move away. However, I have lived here for almost thirty years-there are some people who have been living here since the beginning of the 1970s when this area was built."

During my fieldwork, I frequently came across discussions about the time people had lived in the area, an effective way to confirm the speakers would have grasp of the same social realities. "I am actually very happy to live here," Kirsi continued with a bit of hesitation in her voice, "I know that no one in their right mind would be saying that. I don't bring this up with people who don't live here. To be a decent person you must criticise Kontula....This is really complicated.... also find myself doing that....It happens almost automatically. I must tell you, sometimes I feel that I am stuck in the mood of complaining about how terrible life is here. I could move away if I wanted to, but I am not going to."

We came across Kirsi's neighbour Tanja and stopped to talk about the latest news. There were plans to paint three large murals - then a relatively new but fastgrowing cultural phenomenon in Finland-on their buildings and the rumours circulated widely. Tanja went to the issue straight on: "Why are they coming here, of all places, with this art project? I don't get it." Kirsi replied with a sly grin: "I knew this day would come! We have been hiding here for so long without anyone noticing us. Now these famous foreign artists will come, and the media will follow. Everyone used to be afraid of this place but now they will come to see the murals. It might be that our secret is going to be revealed. Our small paradise will soon be crowded with visitors from all over the world!" We all started to laugh, and they called me another spy about to expose the truth about the neighbourhood.

The theme about being a hidden paradise was another recurrent narrative in Kontula, not limited to this neighbourhood. The residents often challenged the sensationalist media accounts of rampant crime and disorderly conduct in the area but even the official statistics would not help to persuade people who had already made up their minds. However, the demonising representations were countered in an informal register much more often, reversing the whole situation. In this case, the negative media portrayal would become a blessing, protecting the area from outsiders and keeping the place safe from gentrification, rising accommodation costs and the dismantling of its communal spirit. In this case, the supposedly positive public art initiative was experienced as something imposed from the outside, not really touching the everyday lives of the inhabitants. It also pointed to the differences of culturally intimate and more formal ways of approaching changes in the area.

Encounters with Jamal and Kirsi point to two broad themes that expose the dynamics of territorial stigmatisation and responses to it. First, I argue that the hierarchy of spaces is not absolute but is strongly influenced by the social relations of the actors in particular contexts. Following Charles Taylor, the sociospatial hier- 
archies should not be seen as maps inside our heads that can simultaneously relate all points to one another without discrimination, but as moral frameworks that act as guides in changing physical environment, "practical ability unfolding in exercise" (Taylor, 1992, p. 217, 1995, p. 276). Finding an appropriate stance to diverse encounters does not follow pre-formed rules of social interaction but consists of embodied knowledge, spontaneous improvisation of everyday life (Taylor, 1995). Second, the historical layers of the place and its culturally intimate ways of challenging the clichés, stereotypes, and other essentialised representations need to be considered in any analysis intended to address the internalisation of the stigma. Wacquant's analytical framework acknowledges that "relegation in the city is not everywhere cut from the same cloth, in spite of mounting transnational forces and homogenizing discourses" (Wacquant et al., 2014, p. 1271). While I recognise the similarities in the neoliberal policies and their consequences in the global context, I wish to emphasise the role of widely different quotidian responses to territorial stigmatisation.

The responses of both Jamal and Kirsi point to the fine balance between official representations and lived realities. In both cases, the context defines the limits of the appropriate behaviour and rhetoric-the stigmatisation of the subaltern by the dominant sections shaped their encounters with the others, even when the experience of their everyday life did not support it. While Jamal's attempt to challenge the dominant order by claiming not to care about what the others think led to a clash of spatial hierarchies, hesitancy and even shame, Kirsi found a space in which she could express her authentic feelings about her neighbourhood. The question is not about standards of appropriate behaviour as "wired in" or totally imposed by society (Taylor, 1989, p. 9, 1995, p. 168) but about balancing between the official and informal registers in different spatial and sociocultural contexts. The same applies to history: The disorderly palimpsest of official and vernacular histories experienced in the course of everyday life cannot be formalised perfectly; rather than following a set of rules, it must be likewise embodied (Faubion, 1993, p. 62).

For Jamal, the value of his claim of surviving in a hostile environment (and thus everywhere) and "ruling" the milieu around the shopping centre with his friends, was under threat when set against a larger sociospatial hierarchy. At this level, his position in Kontula signified isolation, ignorance, and marginality. On this occasion, his friend Jesse reclaimed the pride by insisting on selfsufficiency ("Kontula has all I need") and ignorance of the values of the dominant hierarchy ("People say this is a shithole, but we don't care"). On the contrary, for Kirsi, the hesitant satisfaction over the homely environment changed into celebration about a hidden paradise, revealed only to people with an intimate connection to the area. Her rhetoric was appropriate in this context, as she said, "to be a decent person you have to criticise Kontula."
A cynical view would hold that these are just futile efforts to challenge the status quo, worthless efforts to fight against the stigma imposed by the dominant actors. However, long-term ethnographic fieldwork gives access to a lifeworld where the dominant understandings of the stigma were challenged by the culturally intimate register of everyday life that emphasised powerful ideas of belonging and local pride. What is notable here is that pride and belonging do not necessarily follow one another in a straightforward manner. Pride is often felt over the very imperfections of sociality rather than the widely recognised and conventional attributes. In the following account, the stigma is reversed and becomes a source of a powerful sense of belonging.

\subsection{Stranger in a Strange Land}

Hasan migrated to Finland from Afghanistan ten years ago and had lived in Kontula almost from the beginning. It had been difficult to find long-term work in Helsinki, but he managed to support himself by working for several companies on an irregular basis. He preferred to spend his time in Kontula and shunned the central districts of Helsinki. Once, we decided to have a beer at the Central Square of the shopping centre on an exceptionally hot summer day. A very drunken middle-aged man was having difficulties walking while singing a famous folk song with his raspy voice. "This is Kontula!", Hasan began smiling, "I really love this atmosphere, it is so unlike the lifeless districts around the city centre. And there is no need to be afraid, nothing has ever happened to me. If you know how to behave, nothing bad will come to you. Every city has a district with a bad name-never mind the reality, the name of the area is enough to remind people of Kontula's reputation. For them, one drunken guy means danger; for me, it means just relaxed normal life. In some other parts of Helsinki, people look at you in a bad way if you are smoking a cigarette while waiting for the bus."

These casual observations led into more fundamental aspects of life:

You know, I have never felt like I belong to Finland. I know the language pretty well, I drink booze like a Finn and many of my friends are ethnic Finns. To some degree I feel that I belong to Helsinki but most of all I belong to Kontula. I can fit in here, but it is not just because there are other immigrants around. In the city centre I feel like an alien, perhaps just like people who are afraid of this place would feel here.

This was another recurring point that I had heard several times. To identify with Kontula more than with a national identity was common among my informants, including ethnic Finns. Many saw Finnish identity as largely ceremonial and distanced from their lifeworld. Hasan was quiet for a little while, took a sip of his beer, and looked like he wanted to balance his contemplation 
with harsh humour: "You can write that I feel at home with the drunks, criminals, and terrorists so everyone will understand!"

Here, like in Kirsi's account above, the slight confusion between formal and informal speech culminated in capturing the (negative) essentialised image of the area and closing the gap between the official narrative and what everyone in Kontula knows is closer to the truth. He was simultaneously located inside and outside these overlapping contexts, a border figure who suffered from lack of recognition and had ambivalent feelings about his place in the society (see Koefoed \& Simonsen, 2012, p. 632). Hasan did not want to be helped, nor understood. He wanted to be left alone by the people who would always misunderstand him because of their version of the truth.

What is remarkable in these culturally intimate contexts is their ordinariness. As Herzfeld (2016, p. 168) argues: "Skilled social performances are not necessarily dramatic or even particularly impressive; on the contrary, some of the most effective performances are among the least palpable." This is why they easily escape the more formal methods of data collection. Consisting of gestures, barely noticeable hints of irony and, at times, overblown exaggerations, they escape the official frameworks, but capture their essentialisations and turn them into powerful claims for belonging. In the accounts of Jamal, Kirsi, and Hasan, living in a "shithole," surrounded by the ugliest buildings in the country and drinking in a disreputable bar are not sources of embarrassment, but of intimacy and affection. Herzfeld's (2016, p. 34) phrase "fellowship of the flawed" captures in an almost poetic manner how the stigma can be challenged in an appropriate sociocultural context and the sense of solidarity and belonging enforced.

\section{Conclusion}

The district of Kontula in the eastern periphery of Helsinki has a long history of territorial stigmatisation. The awareness of the stigma is shared by its inhabitants, but its internalisation is strongly dependent on the context. It is possible to explore the trajectory of the stigmatisation of Kontula from the perspectives of media representations, political developments, and official statistics and question the validity of the stigma, but it nevertheless remains strong. Both residents and non-residents expressed their views alternating between normalising and pathologising portrayals (see Hastings, 2004): alternating between views that the marginalisation has produced a downward spiral of social problems over the years, but also claiming the population is no different from elsewhere in Helsinki and distancing themselves from behavioural explanations. I have argued here that understanding the territorial stigma in Kontula is strongly influenced by the context, that the inhabitants have detailed knowledge about the irreconcilable difference between the denouncements from the powerful actors out- side their lifeworld and the embodied social realities of their everyday lives. While Wacquant's theory of territorial stigma has been important in identifying the structural developments of the neoliberal urban sphere, it does not consider the culturally intimate contexts of everyday life. In Herzfeld's work, the informal register is taken seriously and quotidian work of upholding shared notions of sociality is put into the centre of the analysis. According to this view, a stigmatised area like Kontula also offers opportunities for a positive identification but not necessarily in ways sanctioned by the authorities and the dominant society. In the case of Hasan, his identification was not based on being a Finn but on a more fluid and inclusive notion of living in Kontula and belonging to one of its neighbourhoods. This provides a powerful example of reversing the stigma on a culturally intimate scale (see Koefoed \& Simonsen, 2012, p. 632).

My analysis of the social realities in the area suggests that Bourdieu's and Wacquant's analytical framework of territorial stigma should be complemented with an indepth ethnographic analysis that focusses on the contextual paradoxes and contradictions that escape the more formal methods of data collection. I have explored the constant clash between the formal and informal perceptions of Kontula's neighbourhoods and the skilful balancing between the different registers in rapidly shifting sociospatial contexts. In Kontula, the experience of living in a marginalised and degraded location coexists with an authentic awareness of a vibrant community and a strong sense of belonging. Powerful senses of pride and shame alternate in the everyday lives of the inhabitants who are constantly adjusting their behaviour and rhetoric according to frameworks of appropriate practices. Their transformative potential lies in the ordinariness of these practices, occupying "a militant middle ground between the twin denials of social experience-the extremes of positivism and deconstruction" (Herzfeld, 2016, p. 31) which capacitates them to challenge the dominant discourses from ever-new angles, enabling culturally intimate forms of belonging to thrive.

\section{Acknowledgments}

This work was supported by the Strategic Research Council of the Academy of Finland (Grant No. 312710), Tackling Biases and Bubbles in Participation consortium. I wish to thank the anonymous reviewers for their insightful comments.

\section{Conflict of Interests}

The author declares no conflict of interests.

\section{References}

August, M. (2014). Challenging the rhetoric of stigmatization: The benefits of concentrated poverty in Toronto's Regent Park. Environment and Planning A: 
Economy and Space, 46(6), 1317-1333. https://doi. org/10.1068/a45635

Bourdieu, P. (1999). Site effects. In P. Bourdieu \& A. Accardo (Eds.), The weight of the world: Social suffering in contemporary society (pp. 123-129). Stanford, CA: Stanford University Press.

City of Helsinki. (2018). Statistical yearbook of Helsinki 2018. Helsinki: Executive Office, Urban Research and Statistics.

City of Helsinki. (2019). Population with foreign background in Helsinki 2018-2035. Helsinki: Executive Office, Urban Research and Statistics.

Dhalmann, H., \& Vilkama, K. (2009). Housing policy and the ethnic mix in Helsinki, Finland: Perceptions of city officials and Somali immigrants. Journal of Housing and the Built Environment, 24(4), 423-439.

Duneier, M. (1999). Sidewalk. New York, NY: Farrar, Straus and Giroux.

Duneier, M. (2002). What kind of combat sport is sociology? American Journal of Sociology, 107(6), 1551-1576.

Duneier, M. (2016). Ghetto: The invention of a place, the history of an idea. New York, NY: Farrar, Straus and Giroux.

Faubion, J. (1993). Modern Greek lessons: A primer in historical constructivism. Princeton, NJ: Princeton University Press.

Goffman, E. (1963). Stigma: Notes on the management of spoiled identity. New York, NY: Simon \& Schuster.

Graeber, D. (2007). Possibilities: Essays on hierarchy rebellion and desire. Oakland, CA: AK Press.

Green, S. (2012). On relative location of anthropology: Rethinking the borders. Suomen Antropologi: Journal of the Finnish Anthropological Society, 37(4), 5-10.

Hastings, A. (2004). Stigma and social housing estates: Beyond pathological explanations. Journal of Housing and the Built Environment, 19(3), 233-254. https://doi.org/10.1007/s10901-004-0723-y

Herzfeld, M. (2016). Cultural intimacy: Social poetics and the real life of states, societies and institutions (3rd Ed.). London and New York, NY: Routledge.

Ilmonen, M. (2016). Tulevat lähiöt: Segregaatiota vai gentrifikaatiota [Suburban estates in the future: Segregation or gentrification]. In M. Norvasuo (Ed.), Lähiö ja kaupunki-Asuinalueen rajat muutoksessa [Suburban estate and the city: Changing boundaries of the residential area] (pp. 101-117). Espoo: Aalto University.

Jaskari, K. (2018, February 8). Nämä ovat yleiset syyt muuttaa pois lähiöstä Helsingissä: Humalaisten metelöinti ja monikulttuurisuuden tuomat jännitteet [These are the most common reasons to move out from the suburban estates in Helsinki: Rowdy drunks and multicultural tensions]. YLE. Retrieved from https://yle.fi/uutiset/3-10054215

Jensen, S. Q., \& Christensen, A.-D. (2012). Territorial stigmatization and local belonging: A study of the Danish neighbourhood Aalborg East. City,
16(1/2), 74-92. https://doi.org/10.1080/13604813. 2012.663556

Kallin, H., \& Slater, T. (2014). Activating territorial stigma: Gentrifying marginality on Edinburgh's periphery. Environment and Planning A: Economy and Space, 46(6), 1351-1368. https://doi.org/10.1068/a45634

Kearns, A., Kearns, O., \& Lawson, L. (2013). Notorious places: Image, reputation, stigma. The role of newspapers in area reputations for social housing estates. Housing Studies, 28(4), 579-598. https://doi.org/10. 1080/02673037.2013.759546

Kirkness, P. (2014). The cités strike back: Restive responses to territorial taint in the French banlieues. Environment and Planning A: Economy and Space, 46(6), 1281-1296. https://doi.org/10.1068/a45636

Koefoed, L., \& Simonsen, K. (2012). (Re)scaling identities: Embodied others and alternative spaces of identification. Ethnicities, 12(5), 623-642. https://doi.org/ $10.1177 / 1468796811434487$

Kokkonen, J. (Ed.). (2002). Kontula: Elämää lähiössä [Kontula: Life in the suburban estate]. Helsinki: SKS.

Lento, K. (2006). The role of nature in the city : Green space in Helsinki, 1917-1960. In P. Clark (Ed.), The European city and green space: London, Stockholm, Helsinki and St. Petersburg, 1850-2000 (pp. 188-206). Aldershot: Ashgate Publishing.

Lepistö, J. (2018, August 23). Helsinkiläiskoulun rehtori huolissaan alueiden eriytymisestä: Siihen pitäisi puuttua nyt eikä huomenna, jotta ei kävisi kuin Rinkebyssä [A head teacher in a Finnish school is worried about segregation: One should take action now, not tomorrow-Otherwise this will be like Rinkeby]. MTV-Uutiset. Retrieved from https://tinyurl.com/ yge7hahs

Nelskylä, L. (2016, August 4). Syyrialaista ruokaa, irakilainen parturi ja imut vesipiipusta-Kontulan ostoskeskus elää monikulttuurista nousukautta [Syrian food, Iraqi barber and water pipe cafes-The openair shopping centre of Kontula is nowadays a multicultural success story]. YLE. Retrieved from https:// yle.fi/uutiset/3-9068570

Pajuriutta, S., \& Saarinen, J. (2017, July 25). Kontulan kotihälytykset työllistävät poliisia eniten: "Päiväsaikaan on rauhallista, kun ne kovimmat jätkät nukkuu" [The police visits homes in Kontula more than anywhere else: "In the daytime it is quiet when the tough guys are asleep"] Helsingin Sanomat. Retrieved from https://www.hs.fi/kaupunki/art-2000005301796. html?fbclid=IwAROfgQPWwUGRfn2coR NGglaNPOaOWxldN3wi7Ny_ikQGWq-ty6VljWCmok

Roivainen, I. (1999). Sokeripala metsän keskellä: Lähiö sanomalehden konstruktiona [Lump of sugar in the middle of the forest: Newspaper construction of the suburban estate]. Helsinki: Helsingin Kaupungin Tietokeskus.

Shah, A. (2017). Ethnography? Participant observation, a potentially revolutionary praxis. HAU: Journal of Ethnographic Theory, 7(1), 45-59. https://doi.org/ 
10.14318/hau7.1.008

Stjernberg, M. (2019). Concrete suburbia: Suburban housing estates and socio-spatial differentiation in Finland. Helsinki: Unigrafia.

Taylor, C. (1989). Sources of the self: The making of the modern identity. Cambridge, MA: Harvard University Press.

Taylor, C. (1992). Modernity and the rise of the public sphere. The Tanner Lectures on Human Values, 14, 205-260.

Taylor, C. (1995). Philosophical arguments. Cambridge, MA: Harvard University Press.

Vaattovaara, M., \& Kortteinen, M. (2003). Beyond polarisation versus professionalisation? A case study of the development of the Helsinki region, Finland. Urban Studies, 40(11), 2127-2147.

Vehkasalo, J. (2017a, November 25). Karut luvut ItäHelsingistä: 40 prosenttia parikymppisistä pelkän peruskoulun varassa-"Naapurustolla voi olla suuri vaikutus" [Harsh statistics from the Eastern districts of Helsinki: $40 \%$ of youth around twenty have only comprehensive school education: "The neighbourhood can have a crucial influence]. Helsingin Uutiset. Retrieved from https://www.helsinginuutiset.fi/ artikkeli/583366-karut-luvut-ita-helsingista-40- prosenttia-parikymppisista-pelkan-peruskoulun

Vehkasalo, J. (2017b, June 7). Pariskunta on nähnyt Kontulan ostarin muutokset 50 vuodessa-"Meille tämä on aina ollut hyvä paikka" [This couple has seen how the shopping centre of Kontula has changed in 50 years-"For us this has always been a good place"]. Helsingin Uutiset. Retrieved from https://www. helsinginuutiset.fi/artikkeli/527823-pariskunta-onnahnyt-kontulan-ostarin-muutokset-50-vuodessameille-tama-on-aina

Wacquant, L. (2007). Territorial stigmatization in the age of advanced marginality. Thesis Eleven, 91(1), 66-77. https://doi.org/10.1177/0725513607082003

Wacquant, L. (2008). Ghettos and anti-ghettos: An anatomy of the new urban poverty. Thesis Eleven, 94(1), 113-118. https://doi.org/10.1177/ 0725513608093280

Wacquant, L. (2010). Urban outcasts: A comparative sociology of advanced marginality. Cambridge: Polity Press.

Wacquant, L., Slater, T., \& Pereira, V. B. (2014). Territorial stigmatization in action. Environment and Planning $A$ : Economy and Space, 46(6), 1270-1280. https://doi. org/10.1068/a4606ge

\section{About the Author}

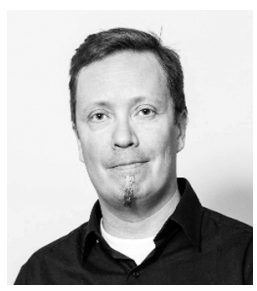

Pekka Tuominen (PhD in Social and Cultural Anthropology) is Post-Doctoral Researcher at the University of Helsinki. His former research deals with the sociocultural dimensions of urban transformation in Istanbul and he is currently leading a multidisciplinary research project in the stigmatised Kontula district of Helsinki, studying the urban transformation of the area and examining new possibilities of participatory urban culture connecting its neighbourhoods. 